\title{
A brief discussion On Graduation Creation Teaching of Fine Arts Major in Colleges and Universities
}

\author{
Kang Xiao \\ Jiangxi Vocational College OF Industry \& Engineering, 337055, China
}

\begin{abstract}
Keywords: colleges and universities; fine arts major; graduation creation teaching
\end{abstract}
\begin{abstract}
The graduation creation of fine arts major is an important content of the teaching of fine arts in colleges and universities. Through the graduation design works, teachers can comprehend the overall learning situation of students and the quality of art teaching. Teachers should comprehensively explore the idea and teaching method of students' graduation creation when carrying out the activities of graduation creation teaching of fine arts majors in colleges and universities. This paper will give a example to discuss the graduation creation teaching of fine arts major in colleges and universities, and put forward personal suggestions.
\end{abstract}

\section{Introduction}

College fine art major includes Chinese painting, printmaking, sculpture, murals, art design and oil painting, and so on. The common characteristics of these six majors is that students should complete graduation creation by collecting creative materials, participating in graduation creation practice and artistic innovation before graduation. From the perspective of teaching, the teaching connotation of graduation creation of fine arts majors in colleges and universities should include students' art knowledge, teaching ideas, methods and abilities. This paper will take Chinese painting, oil painting and printmaking as an example, from the reflection of students' art knowledge skills, integration of modern art creation concept and reflect the national characteristics of graduation creation works to explore the college fine arts major graduation creation teaching program.

\section{To reflect the students' art knowledge skills}

Art is a plastic arts, Chinese painting, printmaking, sculpture, murals, art design and oil painting and other major are all involve the art basic knowledge and professional skills, such as color, sketch, perspective, body structure, art introduction and Chinese and foreign art history, etc. To successfully carrying out the activities of graduation creation teaching of fine arts majors in colleges and universities, teachers should be patient to guide students to review and apply the basic theory knowledge of art, and skillfully handle the shape, color, line and shadow of art works to show the style of the works, and pay attention to graduation creation realistic and reappearance. For students who can use oil paintings as graduation creation works, teachers can guide them to study the history of Western art, absorb the artistic creation factor of the Renaissance, learn the reappearance principles of Spanish naturalism, French romanticism and realism, fusion of colors and make the work to obtain the line freely, the outline clear effect and the incomparable body rhyme change. Teachers can guide students to appreciate the works of the painters such as Diego Rodriguez de Silvay Velazquez, Leonardo Da Vinci, Raphael, Ingres, Eugène Delacroix and Gustave Courbet and create their own unique style ${ }^{[1]}$. For example, when students are asked to appreciate the work of "Las Meninas", "Textile woman", "Pope inocencio x", the teacher can tell the students that Velazquez was originally trained from Herrera and later accepted the naturalistic style of Pacheco training. Most of his early works are religious or stylistic. In 1623, after arrived in Madrid, he painted the portrait of Philippe IV, immediately succeeded, and served as a court painter. His status allowed him to approach the royal collection, including Titian's works, which had a great impact on his style of painting. The Italian tour further developed his style, and returned to Madrid to begin his most creative period. He created a new type of informal portrait for Philippe's hunting 
lodge, and Velazquez's palace dwarf portrait showed the same insight as the royal family. The second time he visited Rome, he painted an excellent portrait of Pope Innocent. In his later years, he created a masterpiece "Las Meninas". In this accidental scene, when the artist was painting for the king and the queen, princess Margaret and her entourage arrived; he created the illusion of a real world in the paintings of people close to the size of the object.

In addition, many Chinese printmaking also take real life as creative elements, which reflect the realism of art works, such as the " Shuihu leaves "," pictures of farming and weaving" and" Bogu leaves " fully integrated the elements of life and folk culture. When instructing students to create printmaking, teachers should pay attention to improve the students' artificial texture processing skills, strengthen students' mastery and understanding of the expression techniques, and teach students to choose the natural texture ${ }^{[2]}$.

\section{Integration of modern art creation concept}

The graduation creation of fine arts majors reflects the students' Art talent and creative ability. Teachers should teach students cognitive research of Chinese and foreign art history, introduction of art, modern art theory, advertising design and numerous schools of art when exploring the idea and teaching method of students' graduation creation, Fusion modern art creation idea, creation unique expression content, technique and style ${ }^{[3]}$. Teachers can let students first study Chinese famous paintings, excavate the connotation of traditional culture, and then fuses the modern artistic creation idea, creates the works with the modern cultural scene. For example, let students study folk customs painting " Along the River During the Qingming Festival ", and then guide students to collect data widely, observe the phenomenon of life, create modern folk customs painting.

\section{To reflect the national characteristics of graduation creation works}

Chinese painting referred to as " traditional Chinese painting ", is our country traditional drawing style, which is using the brush, the ink and the Chinese painting pigment as the material painting on the paper and the silk. It often takes the scenery, the characters, the drawing, the flowers, the birds and beasts as the subject matter, it has a distinctive national character. In highlighting the characteristics of the national character of graduation creation, teachers can guide students to Chinese painting as the carrier, let students understand that intuitive thinking is good at art, especially painting, have a comprehensive understanding of the national character of Chinese painting, and must be further study the painting art and the Chinese painting's characteristic technique. In explaining the graduation creation of Chinese painting, teachers can appropriately introduce the famous words of Osvald Siren, telling students that the " brush can be as thin as a blade, or as wide as a broom. The hand that controls this tool is not on paper, but on wrist freedom. Even the slightest pressure is reflected in the brush marks. This is the most direct and intuitive way to express the pictures or ideas in the artist's mind. It is impossible to modify afterwards. When Chinese painters drawing, they are neither like oil painters, nor are they like those who are careful to copy nature. He fully grasped the picture in his mind, and then did not hesitate to use ink brush to paint. As to whether he uses color rendering, or the use of a dense and thin ink, is relatively irrelevant. Ink brush strokes are always the decisive factor in the meaning and expression of art ${ }^{[4] " .}$

On the other hand, teachers should guide students to inherit the outstanding traditional culture, embody the national character blending the development concept of graduation creation, and use the western art creation factors appropriately, such as letting students enjoy the works of Lin Lin Fengmian, studying the combination of Chinese painting and western painting art, thus instructing students to collect Chinese folk art works, absorbing the valuable artistic creation factors, and creating artworks embodying national cultural characteristics. Teachers can also give the students the story of the master painter Liu Luiling, to tell students that Liu Kuiling has a unique experience in the beauty of the traditional mood, he has a unique understanding of " foreign things serve China ". He uses the tool material of Chinese painting, excavates the western painting realistic spirit to 
obtain just perfect. His painting not only has the fine structure of fine brushwork, but also has the ink and ink freehand brushwork, combination of this two aspects perfect harmony. With its broad drawing road, it has made an important contribution to enrich the development of Chinese painting techniques and explore new areas of expression. Liu Kuiling is good at the construction of " potential ", painting works" The virtual place is not too loose the window frame, the actual place does not feel the board knot tight ", his painting style is elegant and mellow, thick and resourceful, profound artistic conception, the technique is rich and novel, the picture is rich in harmony, fresh and elegant, realistic and the Lord List of wind deities which can be called the unique painting. In order to break through the deadlock of traditional meticulous painting in the art practice and to create a new way for the renovation of traditional painting, Liu Kuiling has devoted his life. He really achieved the perfect fusion of ancient and modern excellent pen and ink tradition, the natural object in the real life, the realistic feeling and the whole sense of western painting and his rich and lively artistic imagination, formed the unique artistic appearance. He created a lot in his life, original " wet silk hair method "," scene lining method ", " count white when black method" and other animal painting techniques, with the pen, color and water flexibly combination, mix in a variety of colors into elegant color, Lifelike performance shows the shape structure and skin color of the birds and animals, and has received excellent artistic effect. This not only can strengthen the students' understanding of traditional painting and Chinese painting skills, but also help to stimulate students' innovative ability and develop students' art techniques.

\section{Concluding remarks:}

To sum up, in the college art graduation creation teaching activities, comprehensive exploration of students' creative ideas and teaching methods, teachers should guide students in art works to reflect their own art knowledge skills, using skilled techniques to deal with the shape, color, line and shadow of art works, to show the style of the work, focus on the realism and reappearance of the graduation creation; fusion of modern art creation idea, highlights the national character of graduation works.

\section{Reference:}

[1]Li Yuliang, Gao Huajun.Research on the reform of graduation creation teaching of college fine arts major [J].Popular literature and art, $2014(07: 1)$

[2]Chen Zhenghong. Research on the teaching practice of graduation creation teaching of fine arts major in colleges and universities [J].Beauty and age, 2014 (09:2)

[3]Qiu Yanfeng, Wang Simeng. Reflections on the graduation creation of fine arts students in colleges and universities [J]. art education, 2011 (12:3)

[4] Hong Libiao. My opinion on the graduation creation teaching course for art majors in colleges and universities [J]. Journal of Jilin Art Institute, 2013 (12:4) 